\title{
Il percorso del Disegno a Messina: dal Collegio di Belle Arti al Dipartimento di Ingegneria. Resoconto di una mostra
}

\author{
Adriana Arena
}

\section{Abstract}

II contributo propone un sintetico spaccato dei temi caratterizzanti la mostra allestita in occasione del $42^{\circ}$ Convegno UID. II filo conduttore che animerà l'evento, che sarà l'evoluzione dell'espressione grafica dalla fine dell'Ottocento ai nostri giorni nel contesto culturale messinese, viene qui articolato attraverso i contenuti, cioè gli elaborati grafici che, insieme ai loro autori, compongono il mosaico delle diverse anime attraverso le quali il disegno si esprimerà nel contesto locale dalla seconda metà del XIX secolo fino ai nostri giorni. Si tenterà una sorta di excursus storico-culturale, una narrazione visiva sul processo di trasformazione dei codici grafici come conseguenza diretta sia della normativa in materia che dell'evoluzione delle tecniche e degli strumenti di rappresentazione. Ciò avverrà principalmente attraverso la produzione grafica dei docenti che si sono avvicendati nell'insegnamento del Disegno, all'inizio all'interno del Collegio di Belle Arti e poi nei corsi istituiti all'interno della Facoltà di Scienze per arrivare, in tempi più recenti alla Facoltà di Ingegneria e, successivamente, al Dipartimento di Ingegneria.

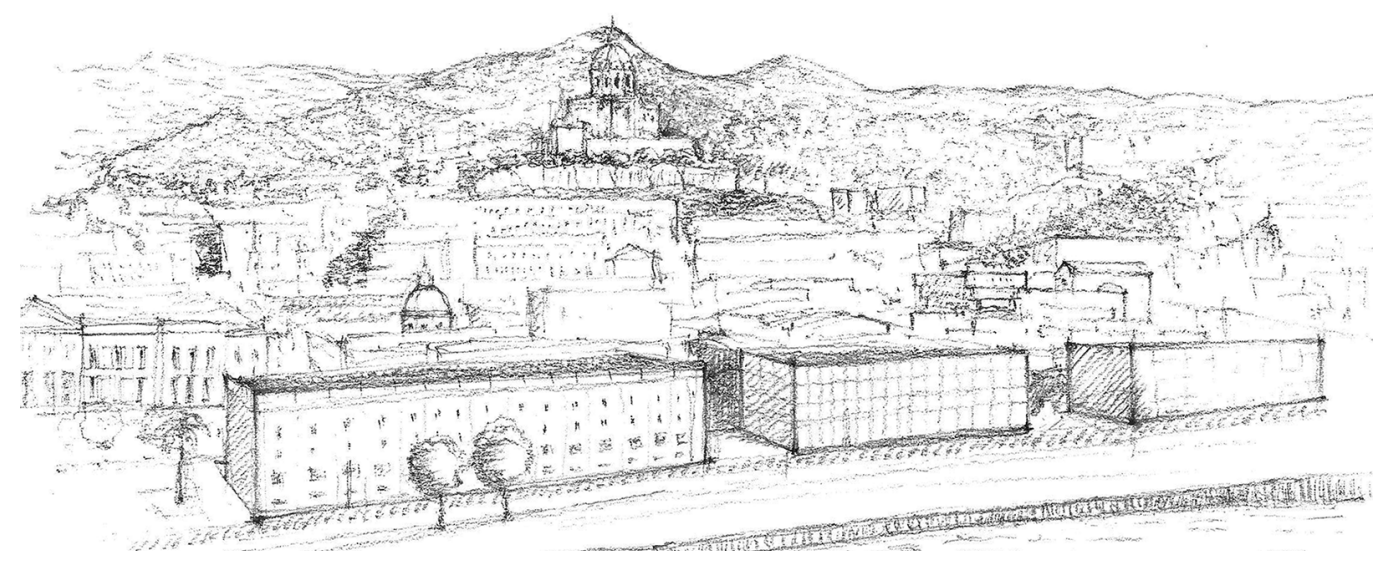




\section{Introduzione}

L'occasione della mostra organizzata come evento collaterale al $42^{\circ}$ Convegno UID rappresenta per la curatrice un'opportunità per ricucire, amplificandola in alcuni dei suoi contenuti, una trama già da qualche anno tessuta intorno ai temi della storia della rappresentazione dell'architettura con particolare riferimento ai corpus iconografici prodotti a partire dalla seconda metà del XIX secolo fino ai primi decenni di quello successivo. In questo caso si è trattato di abbracciare un percorso più ampio e articolato dovendo includere nella ricerca autori che, soprattutto nel periodo iniziale preso in considerazione, possono considerarsi per lo più 'disegnatori' con una maggiore versatilità in campo artistico dovuta alla propria formazione e alla professione, quella di pittore, che poi andranno a esercitare. L'itinerario della mostra svilupperà attraverso una successione di tavole, modelli tridimensionali e documenti originali, che riuniscono sia in successione cronologica che secondo temi ben definiti, le espressioni ritenute più significative delle attività sia dei docenti che si avvicendano nell'insegnamento di questa disciplina sia dei professionisti che, a titolo diverso, operano localmente pur avendo intrapreso inizialmente percorsi formativi in ambiti territoriali diversi. Non disponendo purtroppo di un archivio allinterno dell'Ateneo, probabilmente andato perduto a causa degli eventi sismici e bellici del secolo scorso, nella prima fase della ricerca si è potuto disporre dei dati contenuti allinterno degli Annuari della Regia Università di Messina pubblicati a partire dal 1817 e fino al 1996. Le informazioni più recenti sono state invece desunte dal web nei siti ufficiali dell'Ateneo. Sulla base di quanto riportato da queste fonti si è cominciato a delineare un quadro relativo alle diverse tipologie di insegnamento e alle istituzioni all'interno delle quali i singoli docenti esercitano la didattica.

Ritenendo riduttivo rispetto all'obiettivo prefissato riportare la produzione grafica dei soli docenti impegnati all'interno delle istituzioni accademiche, come accennato in precedenza, è stato dato spazio anche all'attività dei liberi professionisti che operano a Messina sia per ragioni esclusivamente collegate all'attività progettuale che per completare la propria formazione tecnica.

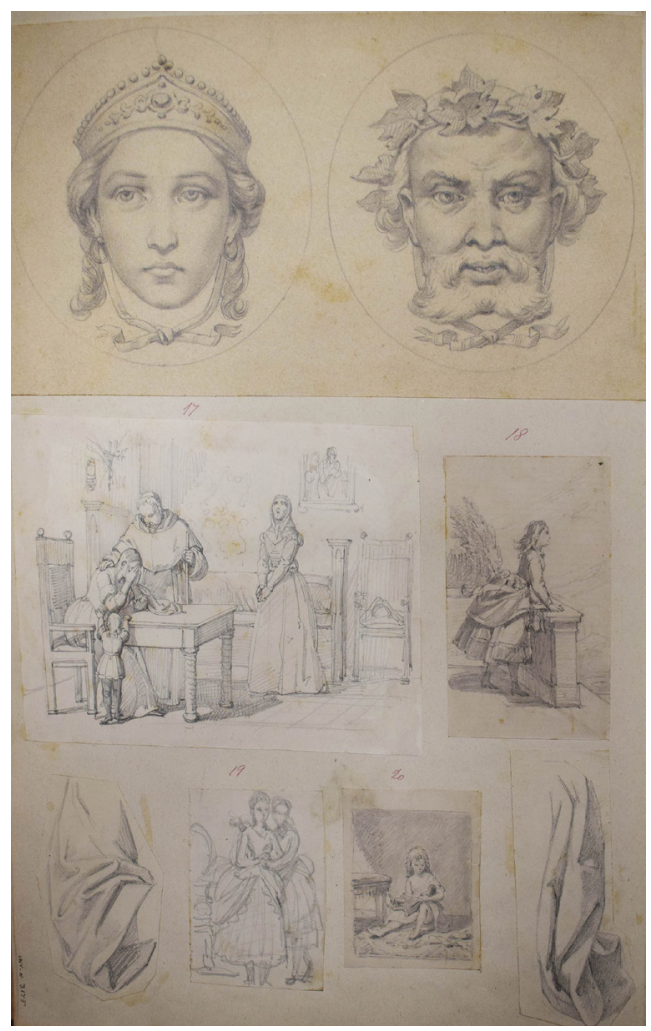




\section{L'insegnamento pubblico del disegno a Messina}

Per tracciare un profilo storico dell'insegnamento pubblico delle discipline inerenti al Disegno a Messina, a partire dal secolo XIX, si può fare riferimento alle strutture a esso dedicate la cui esistenza è documentata quasi esclusivamente attraverso gli elaborati grafici e le biografie dei docenti e degli allievi che si sono maggiormente distinti in ambito sia accademico che professionale. La prima di queste istituzioni è la Scuola di Disegno e Pittura, all'interno dell'Accademia Carolina, che poi confluirà nella Cattedra universitaria di Belle Arti. A livello locale si registra, fino al terremoto del 1908, anche l'attività della Scuola Comunale del Disegno e ancora la Scuola di Disegno della Società Operaia allinterno delle quali transitano alcuni dei docenti che verranno poi incaricati dei corsi presso l'ateneo. L'insegnamento di queste discipline, a partire dal 1870 , proseguirà ininterrottamente all'interno della Facoltà di Scienze [I] fino al 1990 anno di istituzione della Facoltà di Ingegneria che, a partire dal 20 I5, confluirà nell'attuale Dipartimento di Ingegneria.

\section{L'evoluzione del segno grafico}

L'espressione grafica, come è noto, è stata oggetto nel corso dei secoli di profonde e sostanziali trasformazioni che però di fatto non hanno in alcun modo pregiudicato la principale valenza che da sempre ha contraddistinto il disegno è cioè la sua funzione comunicativa. Col passare del tempo essa si è adattata all'evolversi culturale modificando i propri codici affinché fossero comprensibili soprattutto agli addetti del settore anche, nello specifico per il disegno dell'architettura, in relazione all'introduzione di norme che ne hanno consentito una diffusione il più oggettiva possibile.

Il periodo preso in considerazione all'interno della mostra si caratterizza per il passaggio da una forte prevalenza della componente soggettiva presente nei disegni realizzati a un'immagine decisamente oggettiva più aderente e vicina ai canoni e alle istanze dell'architettura razionalista che, proprio nei primi decenni del Novecento, comincia ad affermarsi in tutta Europa. II modus operandi da parte degli esecutori materiali degli elaborati grafici cambia,
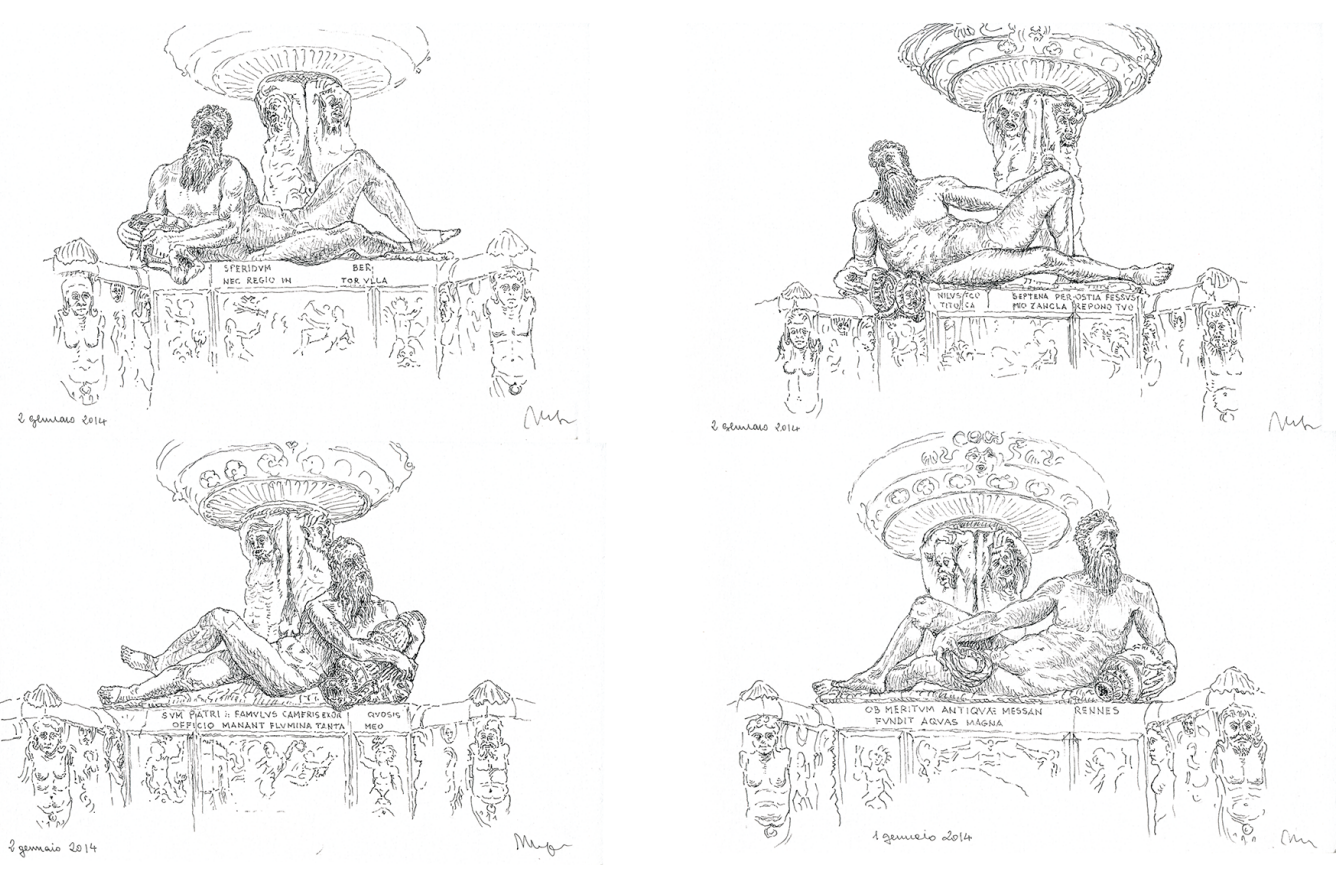
da una particolare preferenza nei confronti di una rappresentazione bidimensionale e di ricorrenti vedute prospettiche, in disegni sempre più orientati a sottolineare gli aspetti tecnologici e più rispettosi delle convenzioni grafiche che verranno definitivamente messe a sistema nell'ambito della normativa UNI a partire dal 192I. In tema di disegno tecnico le nuove regole saranno, in linea di massima, orientate alla razionalizzazione e ottimizzazione dei livelli di comunicabilità del progetto. Si rinuncia gradatamente alle rappresentazioni in prospettiva a favore dell'assonometria che consente una visione più oggettiva dell'architettura percepibile nei suoi rapporti esatti e senza punti di fuga prestabiliti.

Eppure, e sotto certi aspetti per fortuna, nonostante questa progressione verso la spersonalizzazione del segno, perdura, anche nei disegni di progetto realizzati dopo la sistematizzazione delle norme grafiche per la rappresentazione, ma anche nelle realizzazioni contemporanee, quel "margine di libertà che permette una reinterpretazione personale del linguaggio senza comprometterne la lettura" [Rossi 20 I2, p. I7]. Tale peculiarità, insita da sempre nel disegno di progetto, ha fatto sì che esso sia stato oggetto di una duplice valutazione da parte degli studiosi sia per i suoi aspetti più convenzionali legati alla trasmissibilità dei contenuti sia alle maestranze di cantiere o agli organi burocratici di controllo che per le sue caratteristiche formali frutto dell'"'espressione personale degli autori, ricca di 'licenze poetiche' individuali" [Rossi 20 I2, p. 19].

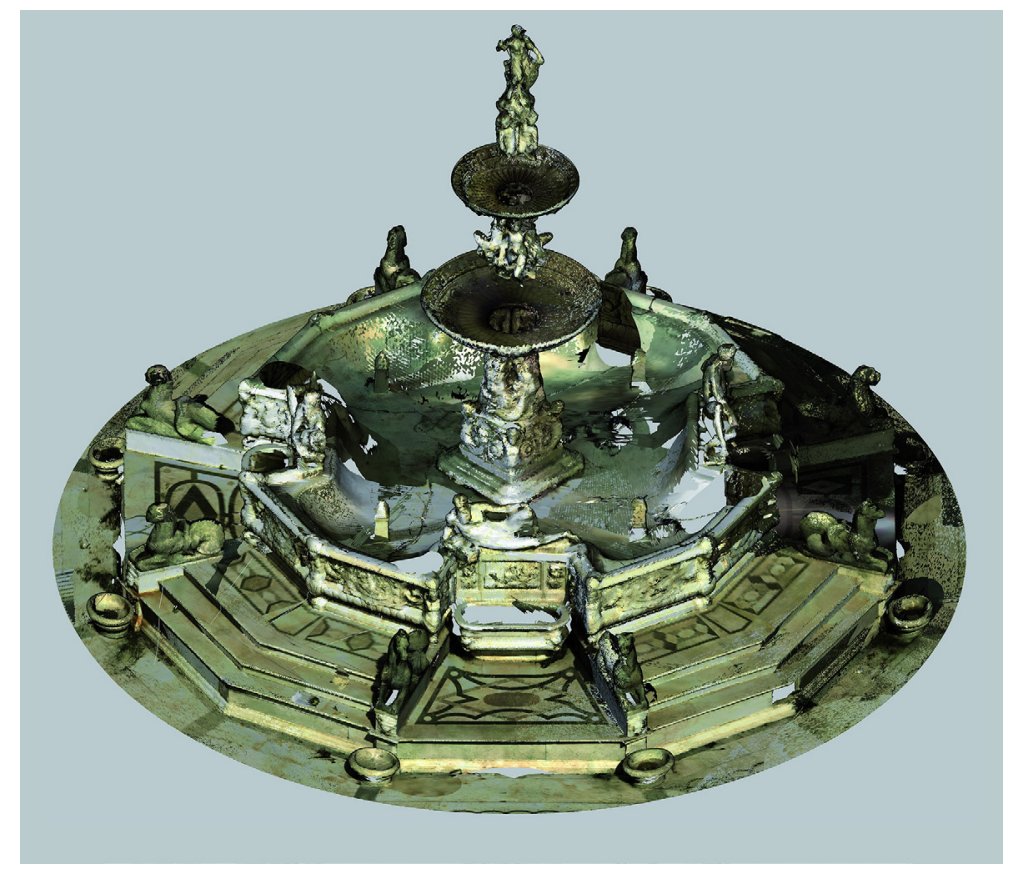

\section{II percorso della mostra}

Il percorso della mostra prevede inizialmente una sezione dedicata a una delle due anime del disegno oggetto di riflessione in questo lavoro e cioè quello artistico che costituisce la materia principale di insegnamento all'interno del Collegio di Belle Arti istituito a Messina a partire dal 1838: suddiviso tra le cattedre di Incisione, Disegno, Pittura e Nudo questa istituzione proseguirà la sua attività fino al I873. I caratteri prevalenti delle opere presentate si possono sintetizzare nella compresenza sia dei retaggi accademici di fine Settecento che dei primi impulsi innovativi derivanti dalle esperienze romantiche ormai dilaganti nel resto d'Europa: "La qualità del disegno, la morbidezza del modellato, la padronanza del mezzo adoperato" [Di Giacomo 1998, p. 105] sono elementi rivelatori sia della buona qualità 
Fig. 4. Leone Savoja, Cimitero di Catania, prospetto principale XIX secolo (collezione privata). della preparazione tecnica impartita agli iscritti dalla scuola messinese che delle relazioni che la stessa intrattiene con istituzioni analoghe nel resto d'Italia (fig. I). Numerosi i disegni conservati presso il Museo Regionale di Messina che hanno come oggetto i principali monumenti cittadini, alcuni non più esistenti o riedificati in altre forme e secondo logiche stilistiche e compositive più coerenti con la nuova epoca di costruzione. Tra i soggetti più replicati c'è sicuramente la fontana di Orione del Montorsoli le cui riproduzioni, eseguite da autori diversi vengono qui riunite in un'unica tavola: in ordine cronologico si tratta dei rilievi a vista eseguiti da J. I. Hittorff ( I 792- | 867), Michele Panebianco (I 806- 1873), Luigi Di Giovanni ( 1856-| 1938), e, in tempi più recenti, da Mario Manganaro (I945-20 I6) e dal suo gruppo di collaboratori. Architetti il primo e l'ultimo, pittori gli altri due, in ogni caso accomunati dal medesimo approccio analitico all'oggetto da rilevare: per Hittorff e Manganaro si tratta di veri e propri rilievi 'scientifici' anche quando sono eseguiti a vista lasciando poco o nulla all'interpretazione soggettiva: tanti tasselli a comporre un complesso monumentale articolato che richiederà per una sua maggiore "comprensione [...] un rilievo più adatto ai tempi ed eseguito con strumenti che ne permettano una rilettura con un grado di approfondimento critico maggiore" [Manganaro 2017, p. I7I]. Da ciò, a completamento di un ragionamento avviato, si associano i più recenti disegni dei rilievi strumentali che indagano il complesso scultoreo confrontandosi con quelli eseguiti da Hittorff nei primi anni del XIX secolo con l'obiettivo di coglierne affinità e distonie e di aprire "nuovi interessanti scenari di approfondimento e ricerca" sul monumento [Altadonna 2017, p. I 89] (figg. 2, 3).

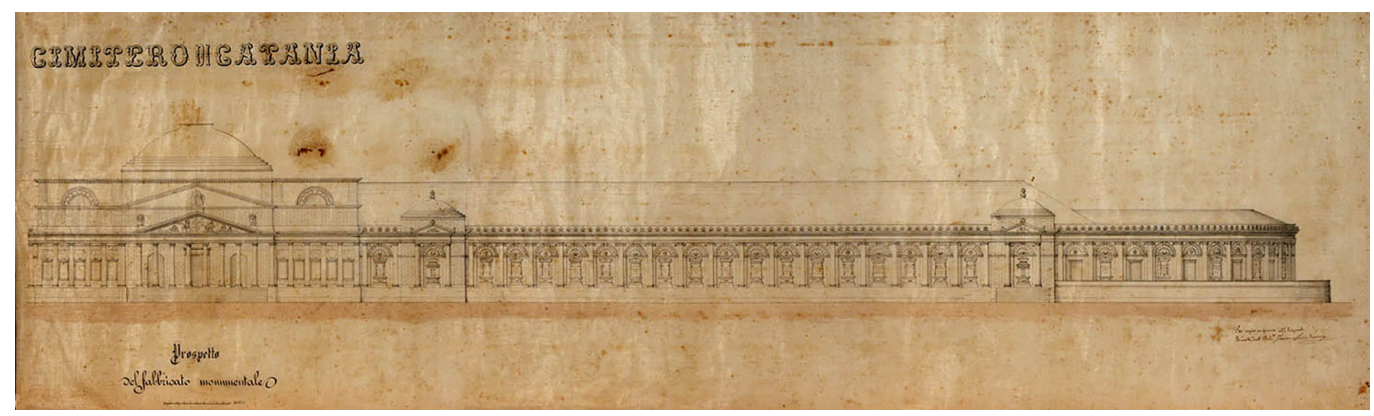

Il percorso della mostra si snoda ancora attraverso le immagini della produzione grafica di alcuni tra i primi docenti di Disegno d'ornato e di Architettura elementare che si avvicendano all'interno della Facoltà di Scienze, come Leone Savoja e Raimondo D'Aronco: il primo, non avendo reperito documentazione grafica riferibile alla sua attività progettuale messinese, viene in questa sede rappresentato dal disegno di un progetto non realizzato del prospetto del cimitero di Catania che si può considerare una chiara dimostrazione di un sedimentato modo di rappresentare che, nonostante i progressi in campo tecnico e tecnologico avvenuti nel XIX secolo, vedeva ancora il progetto di architettura ancorato, anche dal punto di vista grafico, a un eclettismo storicistico con chiari riferimenti quindi a quanto prodotto nel secolo precedente: il virtuosismo architettonico che nel Settecento aveva portato, come in questo caso alla produzione di raffinatissimi grafici evidentemente suscita ancora grande fascino presso i disegnatori del secolo successivo (fig. 4).

I rilievi della chiesa di Santa Maria Alemanna, eseguiti e presentati all'Esposizione Nazionale di Palermo del |89| da Raimondo D'Aronco, ci consentono una rilettura della fabbrica in quel determinato periodo storico (fig. 5).

Nel suo duplice ruolo di docente e di libero professionista la figura di Antonio Zanca a Messina risulta inevitabilmente collegata al progetto della sede municipale per la cui realizzazione viene prodotta un'ingente quantità di disegni: nel loro complesso manifestano un'estrema accuratezza nell'esecuzione, dalle linee più generali fino al minimo dettaglio sia tecnico che ornamentale, assumendo un duplice valore sia di testimonianza artistica, in cui 
Fig. 5. Raimondo D'Aronco, rilievi Chiesa Santa Maria Alemanna, sezione longitudinale,

|89| (Museo Regionale di Messina).
Fig. 6. Antonio Zanca, Progetto Municipio longitudinale, $1914-1924$ (collezione privata).

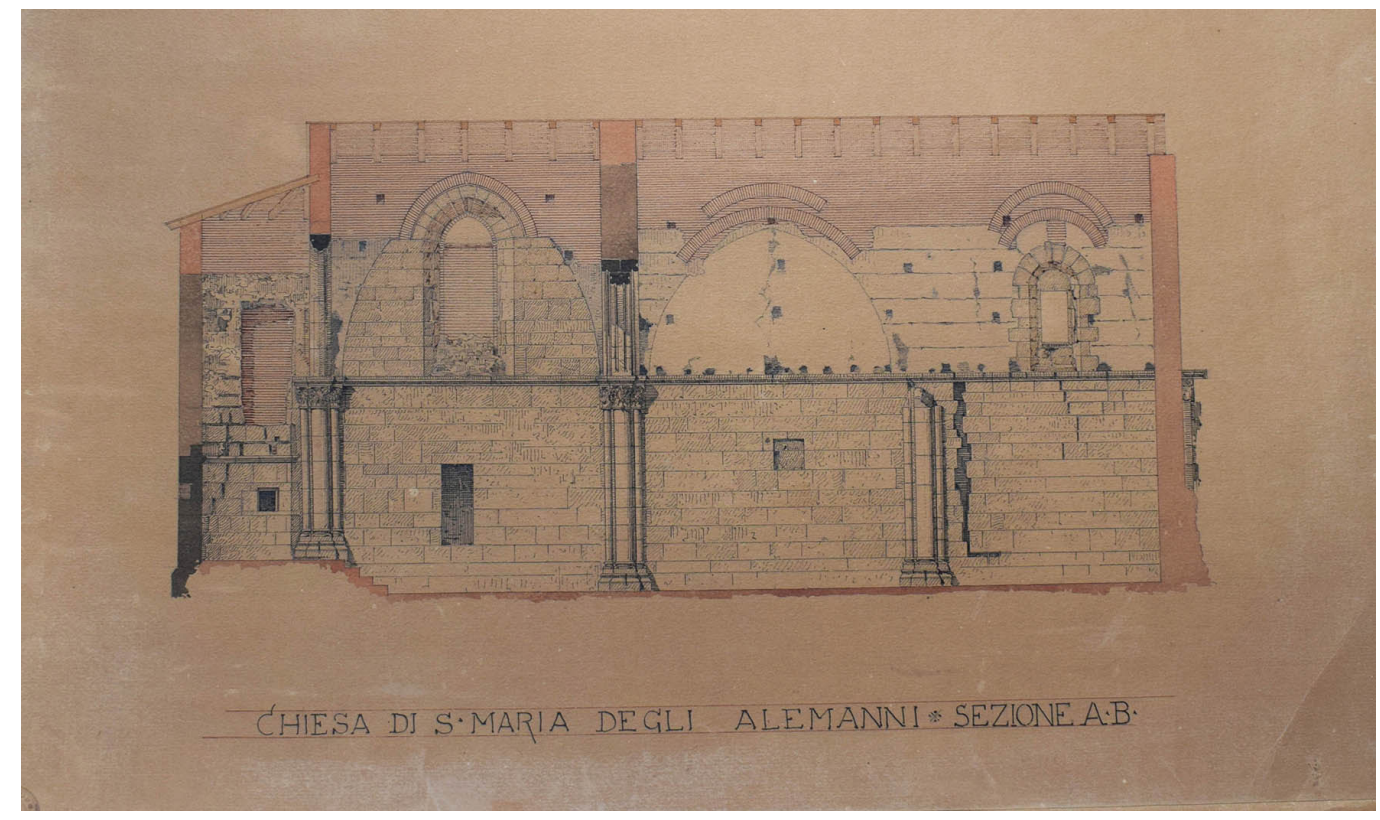

la componente soggettiva diventa elemento caratterizzante nella definizione delle forme e dei volumi, sia di strumento di comunicazione (fig. 6). La vicenda progettuale del Municipio di Messina coinvolgerà, per ciò che riguarda l'allestimento degli apparati decorativi, Adolfo Romano, tra le personalità di spicco in campo artistico a livello locale che, pur formandosi a Roma, raggiunge qui la sua maturità artistica e la notorietà grazie alle committenze per le decorazioni dei nuovi edifici pubblici in cui mette a frutto le esperienze di stampo tardo modernista acquisite nella capitale [Di Giacomo 1998] (fig. 7).

La fatalità del sisma del 1908 richiama a Messina schiere di professionisti, legati insieme dall'obiettivo di sviluppare nuovi temi architettonici partendo dal concetto di rovina come condizione necessaria per ripartire. I concorsi di architettura verranno quindi considerati come luogo privilegiato per il confronto diretto tra diverse correnti di pensiero anche in materia di rappresentazione. Tra i protagonisti della stagione dei concorsi a Messina c'è sicuramente Giuseppe Samonà anche lui impegnato nella docenza presso l'ateneo peloritano insieme a Camillo Autore e a Enrico Calandra nel periodo a cavallo tra le due guerre: nei disegni di concorso per la realizzazione della nuova cortina del porto (1930) presentati da Samonà con Camillo Autore, Guido Viola e Raffaele Leone, si avverte il passaggio, in atto in quel periodo, tra la generazione culturale legata all'espressione grafica del passato e quella

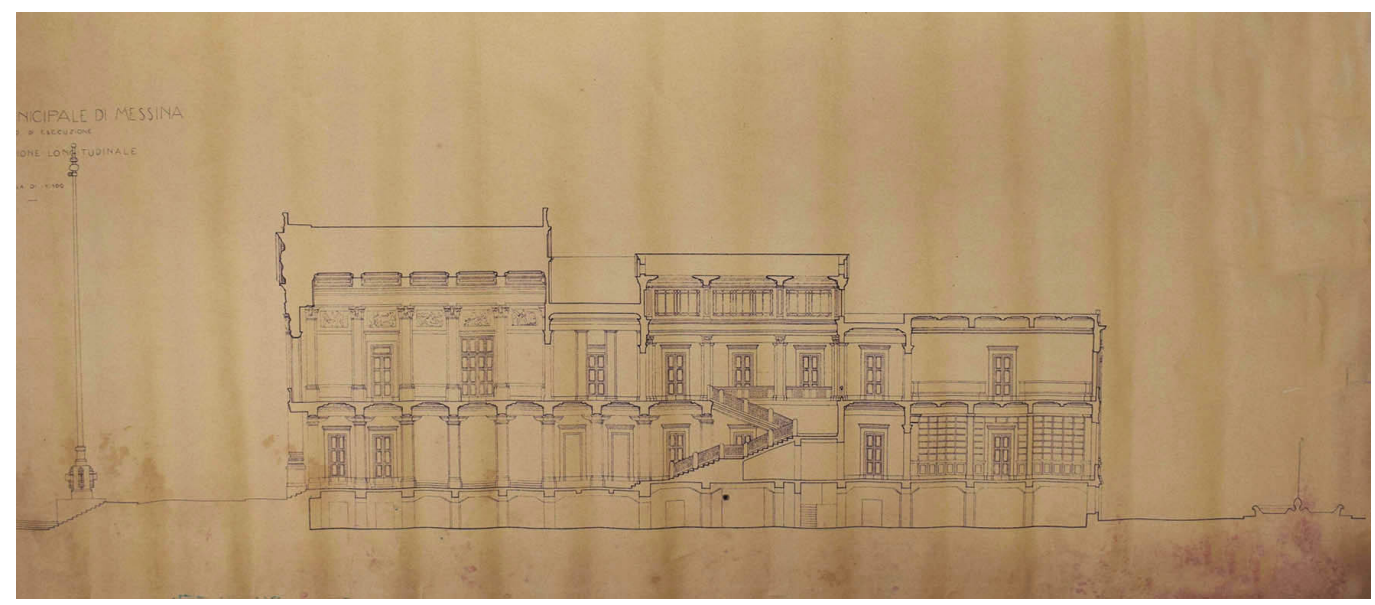


Fig. 7. Adolfo Romano, Bozzetto preparatorio per la decorazione del salone delle feste del Municipio di Messin (collezione privata)

Fig. 8. Giuseppe Samonà, disegno per il Concorso della Nuova Cortina del Porto a Messina testata Porto a Messina, testata (IUAV Archivio progetti)

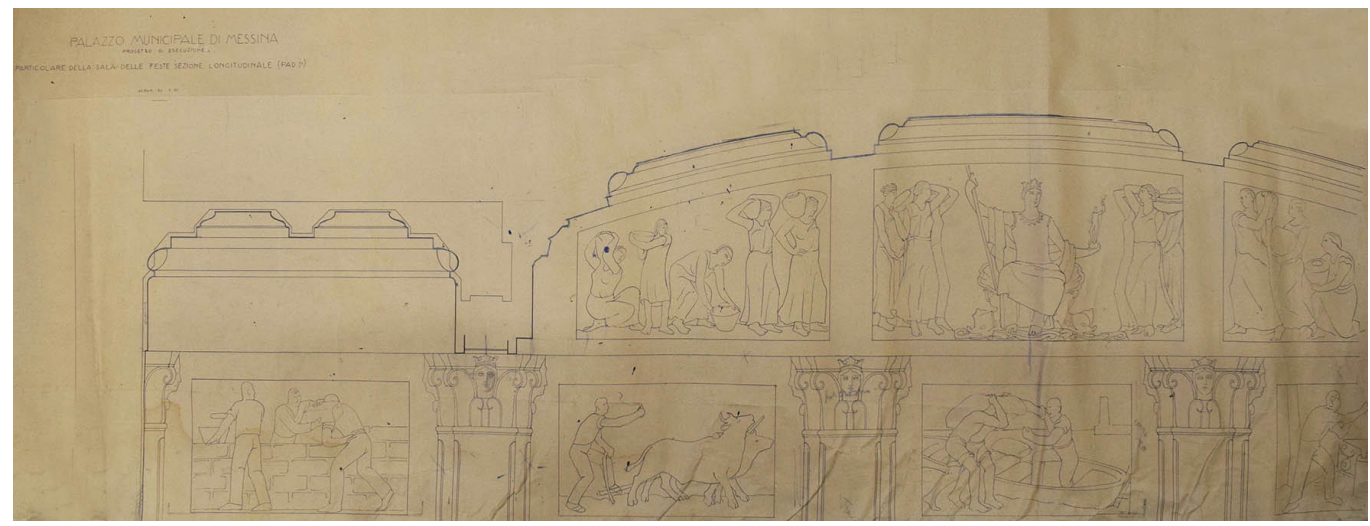

sostenitrice delle nuove istanze figurative: ciò è esemplificabile attraverso gli strumenti e i metodi utilizzati come il carboncino, tradizionalmente più consono alla valorizzazione degli apparati decorativi enfatizzati anche dall'utilizzo delle ombre mentre le prospettive col punto di vista collocato in basso, a esaltare la monumentalità dell'edificio, sono il risultato dell'adesione da parte dei professionisti alle nuove tendenze figurative condizionate dai dettami del regime fascista (fig. 8).

A partire dal 1930 le discipline della rappresentazione a Messina trovano un'adeguata collocazione all'interno dell'Istituto di Disegno che, dal 1935 e fino al 1979, porta avanti le proprie attività sotto la direzione di Francesco Basile, attento studioso di storia dell'architettura e autore di numerose pubblicazioni sui metodi di insegnamento del Disegno. Alla sua scuola si formano, tra gli altri, Giuseppe Arena con i suoi studi e rilievi sui centri minori e, in particolare, sulle chiese normanne calabresi (fig. 9), Fabio Basile, Giovanni Favaloro, Pasquale La Spina e Mario Manganaro. Sull'attività di quest'ultimo sembra veramente riduttivo spendere solo poche righe in questo contesto: i suoi lavori sono sicuramente la testimonianza di un'instancabile attività disegnativa che ha contemperato nell'arco degli anni gli interessi per gli aspetti geometrici della rappresentazione con l'osservazione e restituzione grafica della realtà attraverso una corposa produzione di rilievi a vista: nonostante tale attività sia poco praticata in tempi attuali, questa tipologia di disegni rimane di fondamentale importanza come lo stesso Manganaro ci riferisce poiché "base essenziale per la realizzazione dell'eidotipo di base, per le successive prese metriche e serve in generale per appropriarsi di quelle proprietà primarie e immediate dello spazio architettonico dei centri storici" [Manganaro 2000, p. 62] (fig. 10).

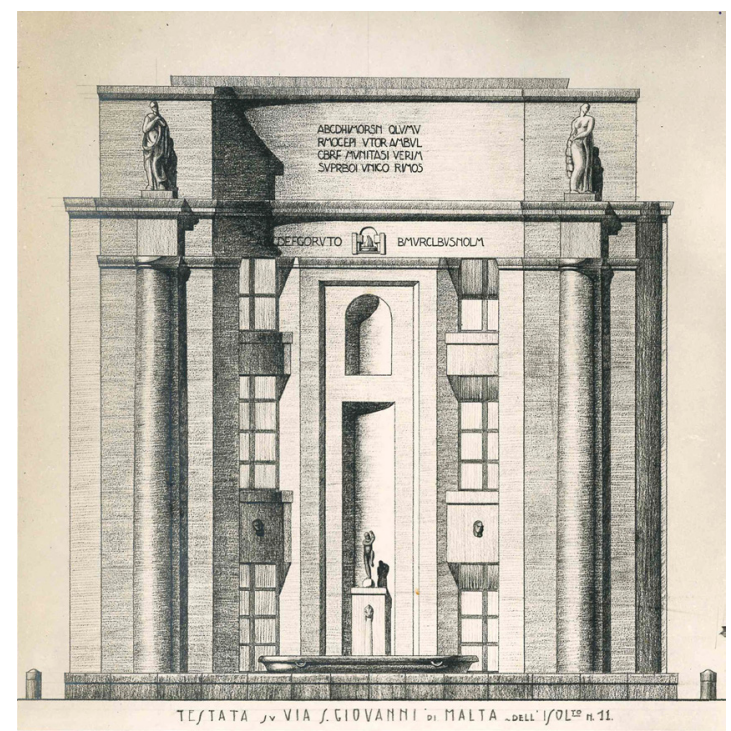




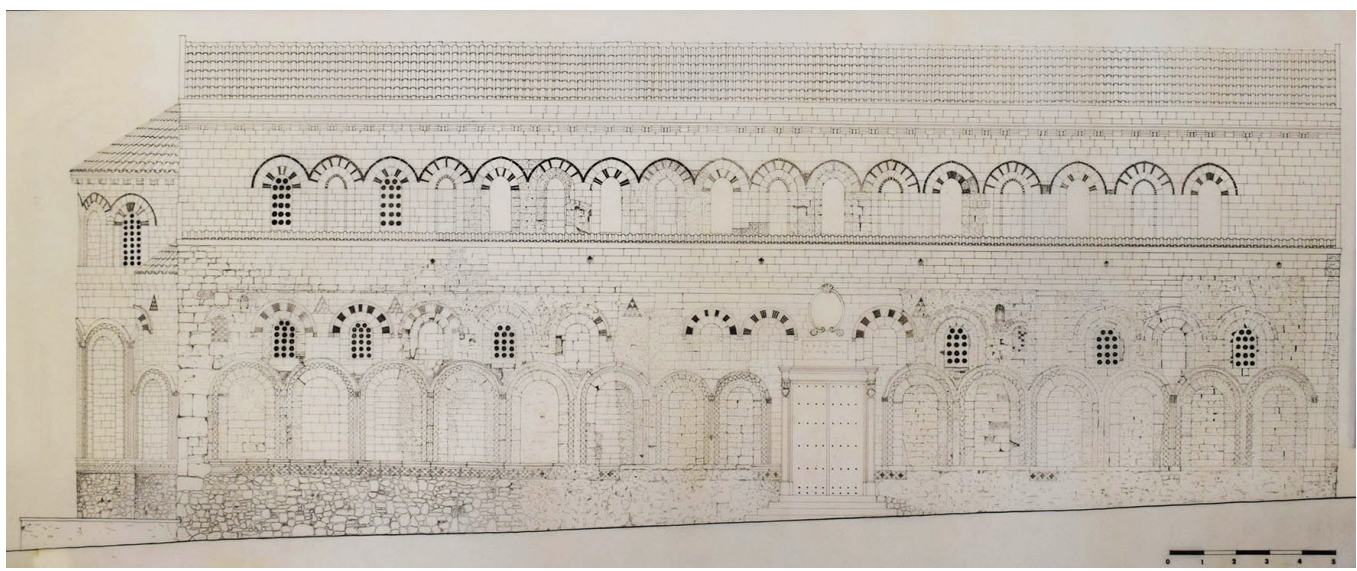

Fig. 10. Mario Manganaro

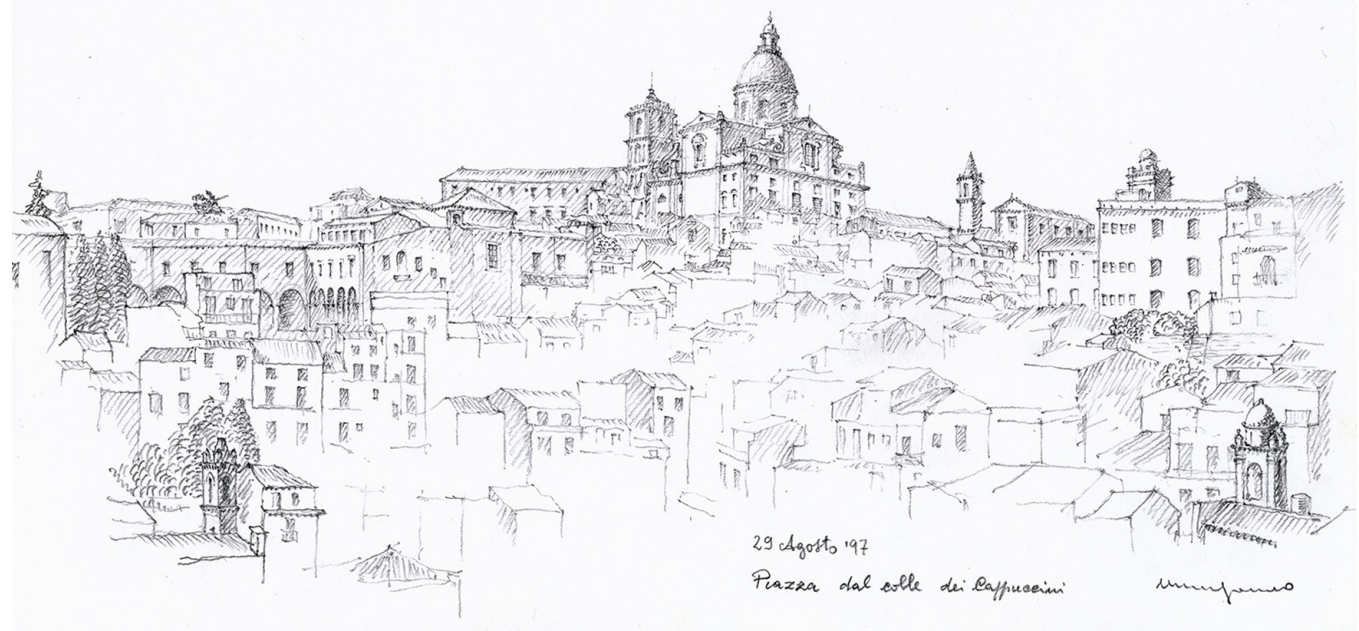


Fig. I I. Michela De Domenico, Gru acquerello e china, 2013

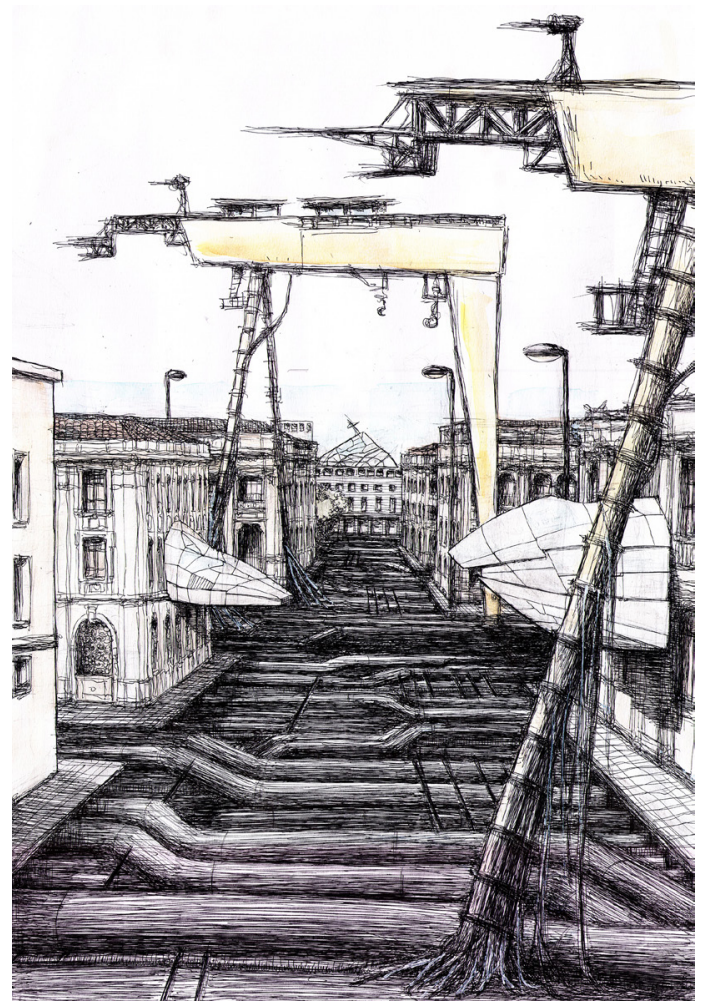

L'attività dell'Istituto di Disegno confluirà, a partire dal 1990, nel Dipartimento di Rappresentazione e Progetto all'interno nella Facoltà di Ingegneria diretta da Fabio Basile.

Questo sintetico resoconto sulla mostra si conclude con un breve spaccato sulle attività di quanti a titolo diverso (docenti, dottorandi, studenti) in tempi recenti hanno portato avanti attraverso gli strumenti del disegno, all'interno dell'attuale Dipartimento di Ingegneria, riflessioni critiche sui temi del progetto e della trasformazione della città: sono gli elementi che contraddistinguono le proposte innovative di Michela De Domenico e Fabrizio Ciappina, entrambe caratterizzate da un approccio visionario: per la prima il disegno di architettura viene indagato attraverso le peculiarità espressive del fumetto (fig. I I), il secondo, nell'esempio proposto, utilizzando uno strumento della tradizione come il gessetto, affronta il tema della ricostruzione di un" "assenza" improvvisa nel tentativo di risarcire un imprevisto vuoto urbano (fig. 12) [2].

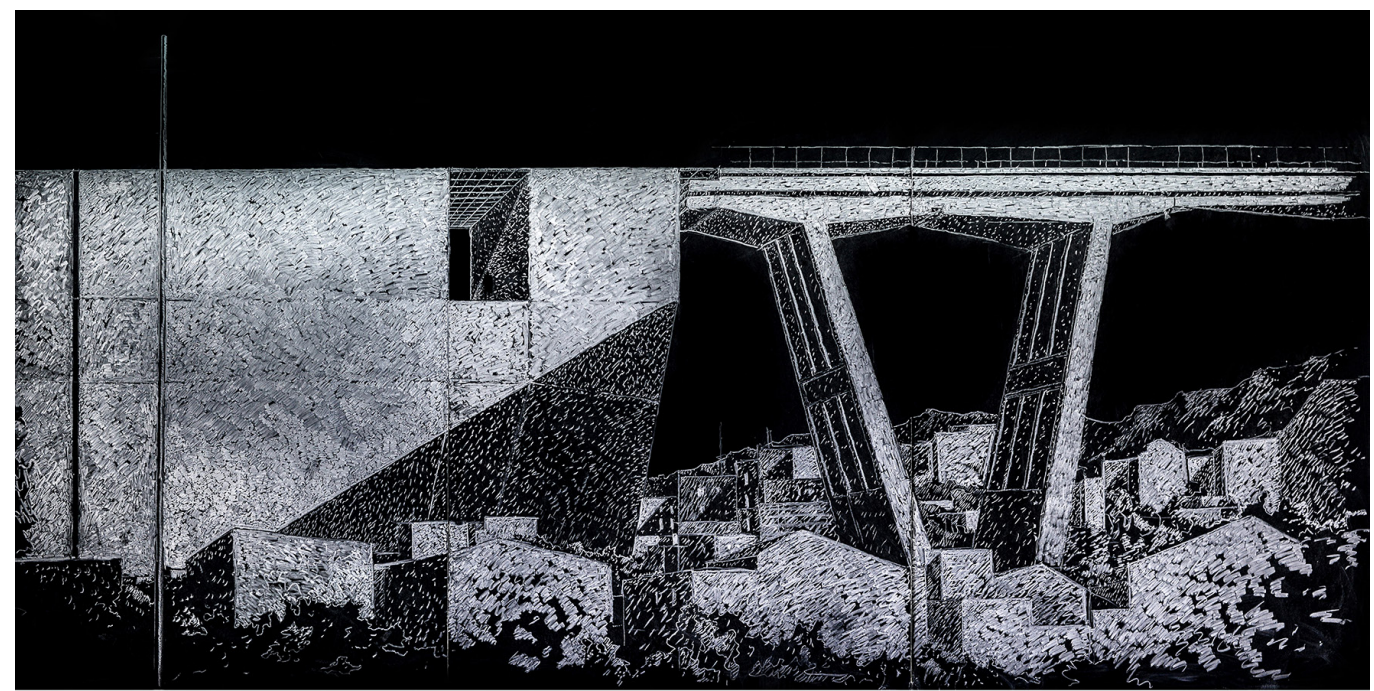




\section{Note}

[I] A partire dal 1929 risulta attivo il biennio propedeutico di Ingegneria nell'ambito dell'Istituto di Disegno della Facoltà di Scienze.

[2] II disegno in copertina è di Angelo Tinnirello (ex allievo ingegnere). Veduta di Messina dal Forte San Salvatore, 20 I 8, realizzato a matita su cartoncino.

\section{Riferimenti bibliografici}

Altadonna Alessio (2017). II rilievo come conoscenza complessa e integrata: il caso di studio della fontana di Orione in Messina. In Kiene Michael, D’Angelo Michela, Lo Curzio Massimo (a cura di). 1823 Hittorff a Messina. La scoperta di una città nuova. Messina: EDAS, pp. |83-191.

Di Giacomo Caterina (1998). II disegno a Messina fra i due secoli: retaggi accademici ed impulsi innovativi. In Barbera Gioacchino (a cura di). Gli Anni dimenticati. Pittori a Messina tra otto e novecento. Messina: Sicania, pp. I03-I I I.

Manganaro Mario (2000). Apparizioni di città. [Sceneggiatura]. In Aricò Nicola (a cura di). DRP Rassegna di Studi e Ricerche, 3 , pp. $45-72$.

Manganaro Mario (2017). Rilievo della fontana di Orione. Rapporto preliminare. In Kiene Michael, D'Angelo Michela, Lo Curzio Massimo (a cura di). 1823 Hittorff a Messina. La scoperta di una città nuova. Messina: EDAS, pp. I65- 181.

Rossi Michela (2012). La forma e la norma: il linguaggio dei segni. In Rossi Michela (a cura di). Il disegno come ricerca. Strumenti grafici e modelli rappresentativi per il progetto. Santarcangelo di Romagna: Maggioli Editori, pp. 17-26.

Vernizzi Chiara (2005). Codici del disegno di progetto. Considerazioni sull'innovazione dei modi di rappresentazione determinata dalle mutate necessità operative. In Mochi Giovanni (a cura di). Teoria e pratica del costruire: saperi, strumenti, modelli. Esperienze didattiche e di ricerca a confronto. Atti del Seminario Internazionale. Ravenna, 27-29 ottobre 2005, vol. I, pp. 37I-380. Ravenna: Edizioni Moderna.

Autore

Adriana Arena, Università di Messina, adarena@unime.it

Per citare questo capitolo: Arena Adriana (2020). Il percorso del Disegno a Messina: dal Collegio di Belle Arti al Dipartimento di Ingegneria. Resoconto di una mostra/The path of Drawing in Messina: from the College of Fine Arts to the Engineering Department. Report of an exhibition. In Arena A., Arena M., Brandolino R.G., Colistra D., Ginex G., Mediati D., Nucifora S., Raffa P. (a cura di). Connettere. Un disegno per annodare e tessere Atti del $42^{\circ}$ Convegno Internazionale dei Docenti delle Discipline della Rappresentazione/Connecting. Drawing for weaving relationships. Proceedings of the 42th International Conference of Representation Disciplines Teachers. Milano: FrancoAngeli, pp. I $578-1597$. 


\title{
The Path of Drawing in Messina: from the College of Fine Arts to the Engineering Department. Report of an Exhibition
}

\author{
Adriana Arena
}

\section{Abstract}

The contribution offers a synthetic cross-section concerning the themes characterizing the 42nd UID Conference exhibition. The guiding thread that will animate the event, namely the evolution of graphic expression from the end of the nineteenth century to the present day in Messina cultural context, is articulated here through the contents, i.e. the elaborate graphics that, together with their authors, compose the mosaic of the different souls through which the design will express itself in the local context from the second half of the 19th century to the present day. A sort of historical-cultural excursus will be attempted, a visual narrative on the process of transforming the graphic codes as a direct consequence of both the legislation on the matter and the evolution of techniques and tools of graphic representation. This will mainly take place through the graphic production of the teachers who have alternated in the teaching of Drawing, initially within the College of Fine Arts and then in the courses set up within the Faculty of Sciences to arrive, in more recent times, at the Faculty of Engineering and, subsequently, to the Department of Engineering.

Keywords

exhibition, teaching of drawing, graphic documentation, graphic expression.

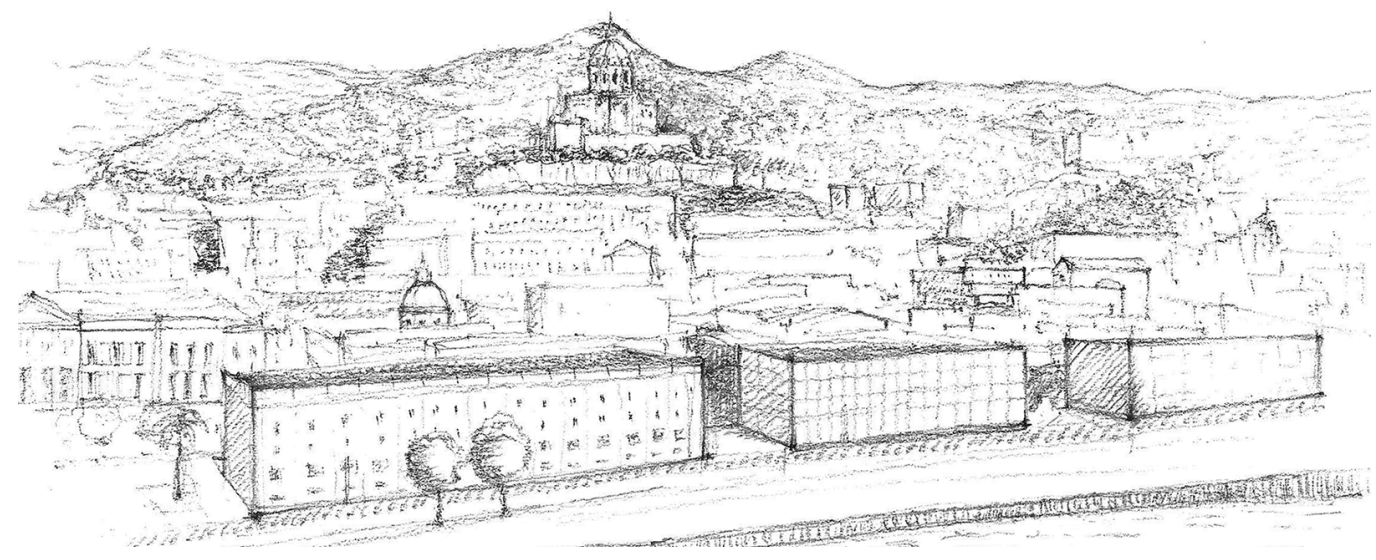




\section{Introduction}

The occasion of the exhibition organized as a side event at the 42nd UID Conference represents for the curator an opportunity to mend, amplifying it in some of its contents, a plot already for some years woven around the themes of the history of architecture representation with particular reference to the iconographic corpus produced from the second half of the 19th century until the first decades of the following one. In this case it was a matter of embracing a wider and more articulated path, having to include in the research authors who, especially in the initial period taken into consideration, can be considered mostly 'draftsmans' with greater versatility in the artistic field due to their training and profession, that of painter, which then they will go to practice. The itinerary of the exhibition develops through a succession of tables, three-dimensional models and original documents, which bring together, in chronological succession and according to well-defined themes, the expressions deemed most significant of the activities and of the teachers who take turns in teaching this discipline both professionals who, in different capacities, operate locally despite having initially started training courses in different territorial areas.

Unfortunately, not having an archive inside the University, probably lost due to the seismic and war events of the last century, in the first phase of the research it was possible to have the data contained in the Annuari della Regia Università di Messina published from 1817 to 1996. The most recent information was instead taken from the web on the official University websites. By analysis of what is reported by these sources, a framework has begun to be drawn up relating to the different types of teaching and the institutions within which the individual teachers exercise teaching.

Considering that the graphic production of only the teachers engaged within the academic institutions, as mentioned above, was reductive compared to the set objective, space was also given to the activity of freelancers who work in Messina both for reasons exclusively related to design activity as well as to complete their technical training.

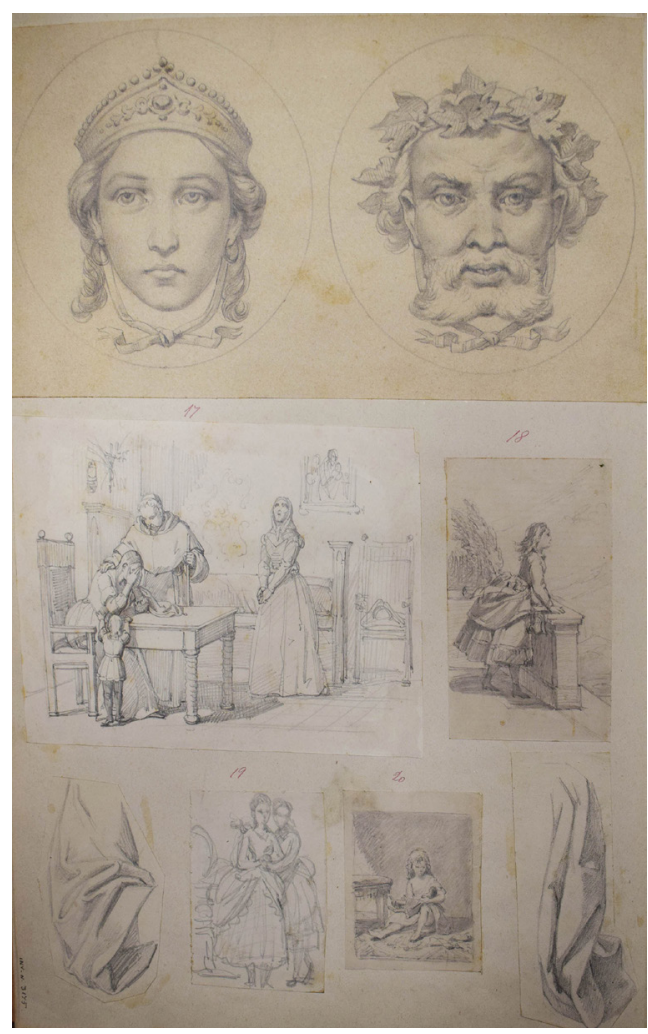




\section{Public teaching of drawing in Messina}

To trace an historical profile of the public teaching of the disciplines inherent drawing in Messina, starting from the nineteenth century, it is possible to refer to the deployed structures whose existence is documented almost exclusively through the graphics and biographies of the teachers and students who have distinguished themselves more in both academic and professional fields. The first of these institutions is the School of Drawing and Painting, inside the Carolina Academy, which will then flow into the Cattedra Universitaria di Belle Arti. At the local level, until the earthquake of 1908, there is also the activity of Scuola Comunale del Disegno as well as Scuola di Disegno della Società Operaia where are starting their professional excursus some of the teachers who will then be in charge of the courses within the university. The teaching of these disciplines, starting from 1870, will continue uninterruptedly within the Faculty of Science until 1990, the year of establishment of the Faculty of Engineering which, starting from 2015, will flow into the current Department of Engineering.

\section{The evolution of the graphic sign}

As well recognized, the graphic expression has been the object of profound and substantial transformations over the centuries which however have in no way compromised the main value that has always distinguished the design, that is, its communicative function. Over time it has adapted to the cultural evolution by modifying its codes so that they are understandable above all to those working in the sector also, specifically for the design of architecture, in relation to the introduction of rules that have allowed it to be disseminated the most objective possible.

The period taken into consideration in the exhibition is characterized by the passage from a strong prevalence of the subjective component present in the drawings constructed by use of an objective image that is more adherent and close to the canons and instances of rationalist architecture which, right in the first decades of the twentieth century, begins to assert
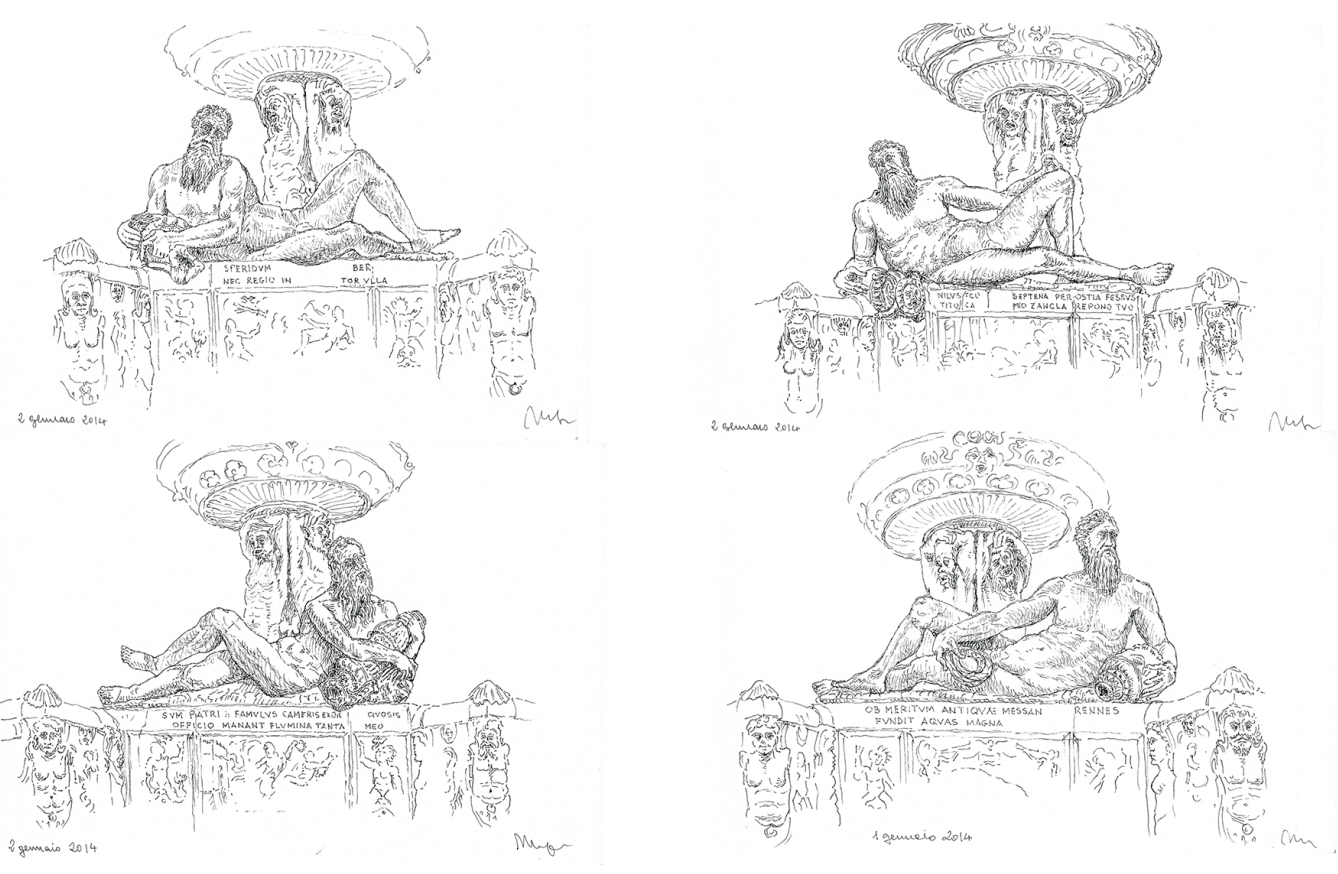
itself throughout Europe. The modus operandi on the part of the material executors of the graphic design changes, from a particular preference for a two-dimensional representation and recurring perspective views, into drawings increasingly oriented to underline the technological and more respectful aspects of the graphic conventions that will be definitively put to use. system within the UNI standard starting from 1921. As regards technical design, the new rules will, in principle, be oriented towards the rationalization and optimization of the communicability levels of the project. Gradually renouncing representations in perspective in favor of axonometry that allows a more objective view of architecture perceivable in its exact relationships and without predetermined vanishing points.

Yet, and in some respects fortunately, despite this progression towards the depersonalization of the sign, that "margine di libertà che permette una reinterpretazione personale del linguaggio senza comprometterne la lettura" [Rossi 20 I2, p. 17]. This peculiarity, always inherent in the project design, has meant that it has been the subject of a double evaluation by scholars both for its more conventional aspects related to the transmissibility of contents and to site workers or bureaucratic control bodies that for its formal characteristics, the result of the "espressione personale degli autori, ricca di 'licenze poetiche' individuali" [Rossi 20 I2, p. 19].

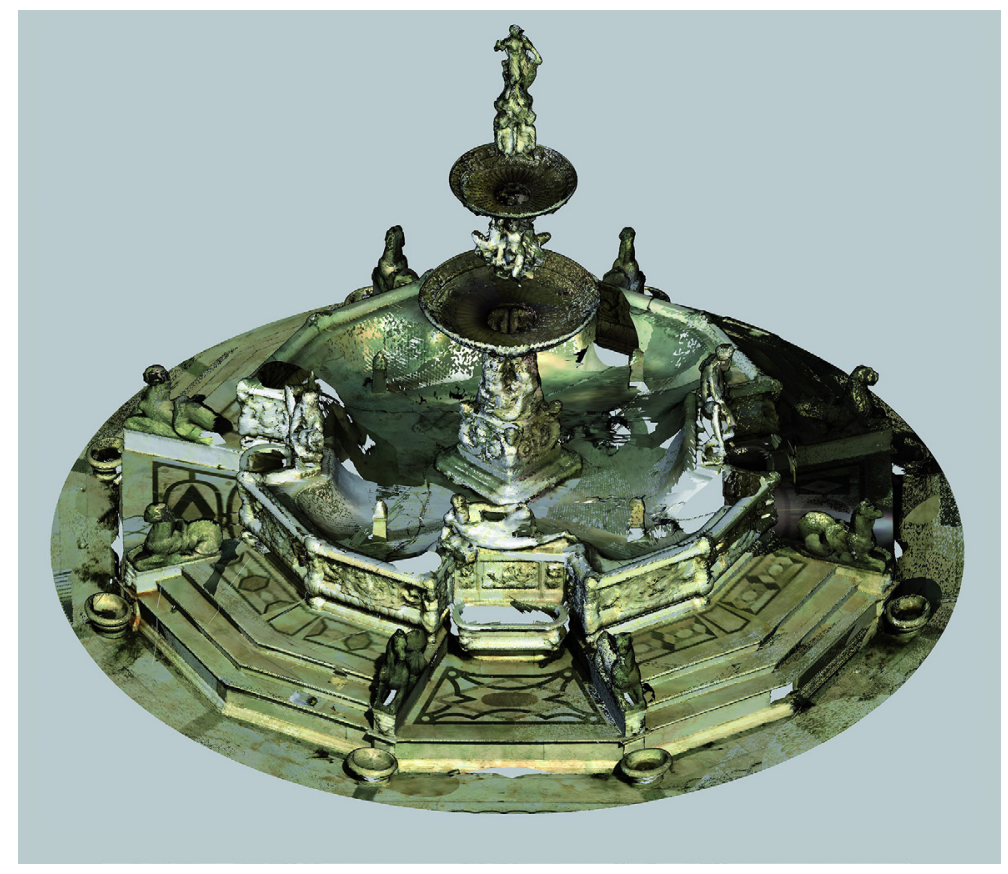

\section{The path of the exhibition}

The course of the exhibition initially includes a section dedicated to one of the two souls of the drawing that is the object of analysis in this work, that is, the artistic one which constitutes the main teaching subject within the Collegio di Belle Arti established in Messina starting from 1838: divided among the chairs of Engraving, Drawing, Painting and Nude this institution will continue its activity until I 873. The prevailing characters of the works presented can be summarized in the co-presence of both the late eighteenth century academic heritage and the first innovative impulses deriving from the now rampant romantic experiences in the rest of Europe: "La qualità del disegno, la morbidezza del modellato, la padronanza del mezzo adoperato" [Di Giacomo 1998, p. 105] are revealing elements both of the good 
quality of the technical preparation imparted to the students of the Messina school and of the relationships that it maintains with similar institutions in the rest of Italy(fig. I). Numerous drawings kept at the Regional Museum of Messina which have as their object the main city monuments, some no longer existing or rebuilt in other forms and according to stylistic and compositional logics more consistent with the new era of construction. Among the most replicated subjects there is certainly the Orion Fountain by Montorsoli whose reproductions, made by different authors are gathered here in a single table: in chronological order they are the visible surveys made by J.I. Hittorff (1792-1867), Michele Panebianco ( 1806 - I 873), Luigi Di Giovanni (1856-1938), and, more recently, Mario Manganaro (19452016) and his team of collaborators. The first and last architects, the other two painters, in any case characterized by the same analytical approach to the object to be detected. For Hittorff and Manganaro these are 'scientific' survey findings even when they are executed on sight leaving little or no nothing to the subjective interpretation: many pieces to make up an articulated monumental complex that will require for its greater "comprensione [...] un rilievo più adatto ai tempi ed eseguito con strumenti che ne permettano una rilettura con un grado di approfondimento critico maggiore" [Manganaro 2017, p. 17I]. From this, to complete a reasoning started, the most recent drawings of the instrumental surveys that investigate the sculptural complex are associated, comparing with those made by Hittorff in the early nineteenth century with the aim of grasping affinities and dystonies and opening up "nuovi interessanti scenari di approfondimento e ricerca sul monumento" [Altadonna 2017, p. 189] (figs. 2, 3).

Fig. 4. Leone Savoja, Catania cemetery,main elevation, 19 th century (private collection).

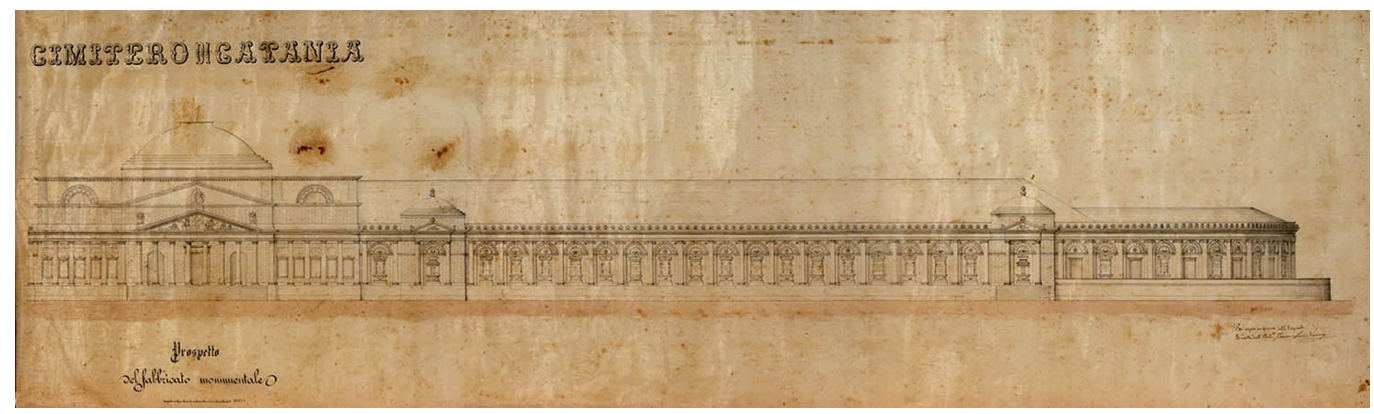

The path of the exhibition still winds through the images of the graphic production of some of the first teachers of Ornate Drawing and elementary Architecture, who alternate within the Faculty of Sciences, such as Leone Savoja and Raimondo D'Aronco: the first, since it has not been found any graphic documentation referable to its Messina design activity, it is represented here by the drawing of an unrealized project of the prospect of the Catania cemetery which can be considered a clear demonstration of a sedimented way of representing that, despite the progress in the technical and technological field that took place in the 19th century, he still saw the architectural project anchored, also from the graphic point of view, to a historicistic eclecticism with clear references therefore to what was produced in the previous century: the architectural virtuosity that in the eighteenth century had brought, as in this case the production of very refined graphics evidently arouses still great charm among the designers of the following century (fig. 4).

The reliefs of the church of Santa Maria Alemanna, executed and presented at the National Exhibition of Palermo in I89I by Raimondo D'Aronco, allow us to reconsider the factory in that particular historical period (fig. 5).

In his dual role as a teacher and freelancer, the figure of Antonio Zanca in Messina is inevitably connected to the project of the municipal headquarter for which a huge amount of drawings is produced: overall they show extreme accuracy in the execution, from the more general lines to the smallest technical and ornamental details, taking on a double value 
Fig. 5. Raimondo D'Aronco, surveys Church of Santa Maria Alemanna, longitudinal section, I89 (Regional Museum of Messina).

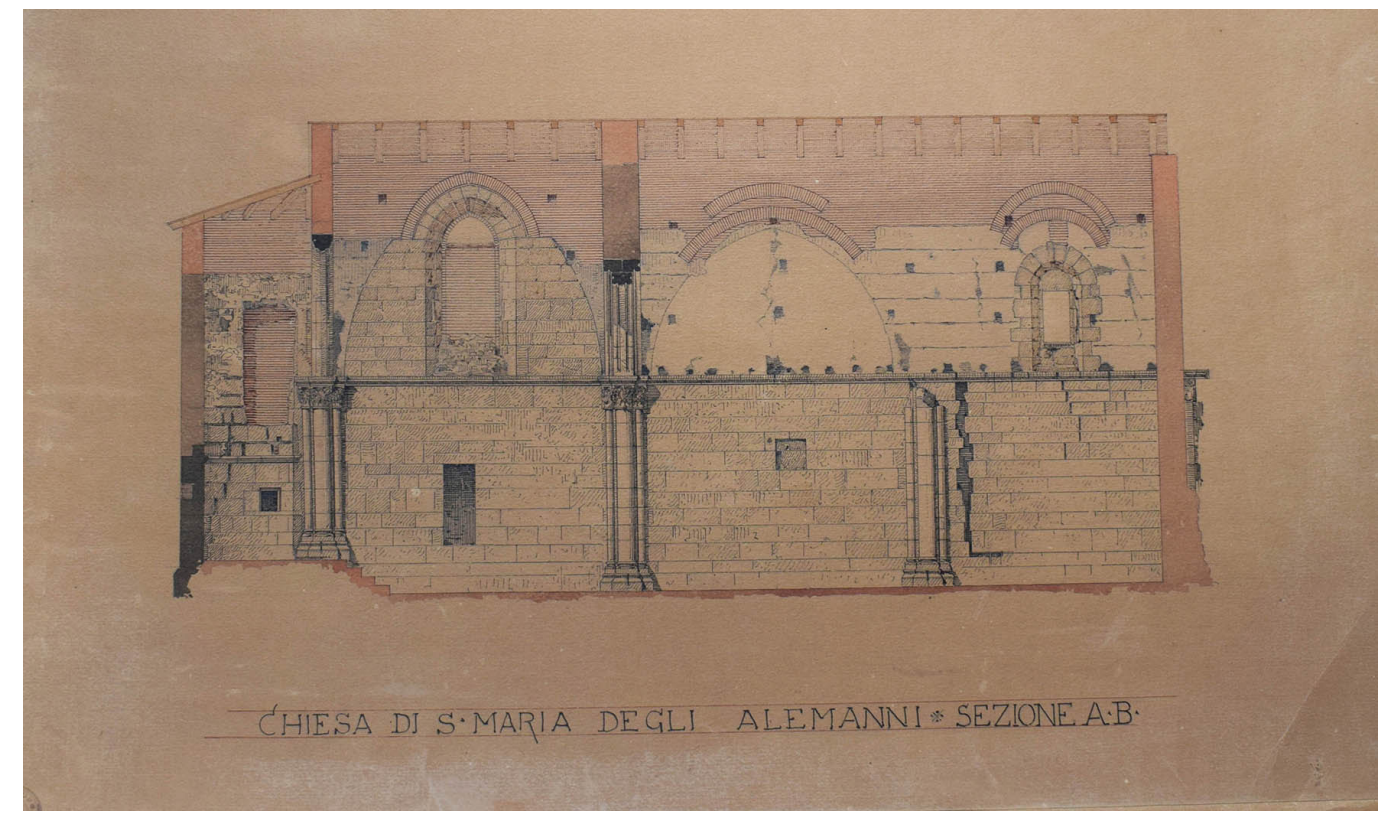

both as an artistic testimony, in which the subjective component becomes a characterizing element in the definition of shapes and volumes, and as a communication tool (fig. 6). The agenda concerning the design of the Municipality of Messina will involve Adolfo Romano, among the prominent personalities in the artistic field at the local level, which, despite being formed in Rome, reaches its artistic maturity and fame thanks to the orders for the decorations of the new public buildings where he uses the late modernist experiences acquired in the capital [Di Giacomo 1998] (fig. 7).

The fatality of the 1908 earthquake pushes groups of professionals to reach Messina, linked together by the goal of developing new architectural themes starting from the concept of ruin as a necessary condition to start again. The architectural competitions will therefore be considered as a privileged place for the direct comparison between different currents of thought also in the matter of representation. Among the protagonists of the competition season in Messina there is certainly Giuseppe Samonà who is also engaged in teaching at the "Peloritana" university together with Camillo Autore and Enrico Calandra in the period between the two wars: in the competition drawings for the construction of the new "Cortina del Porto" ( 1930) presented by Samonà with Camillo Autore, Guido Viola and Raffaele Leone, there is a shift, taking place in that period, between the cultural generation linked

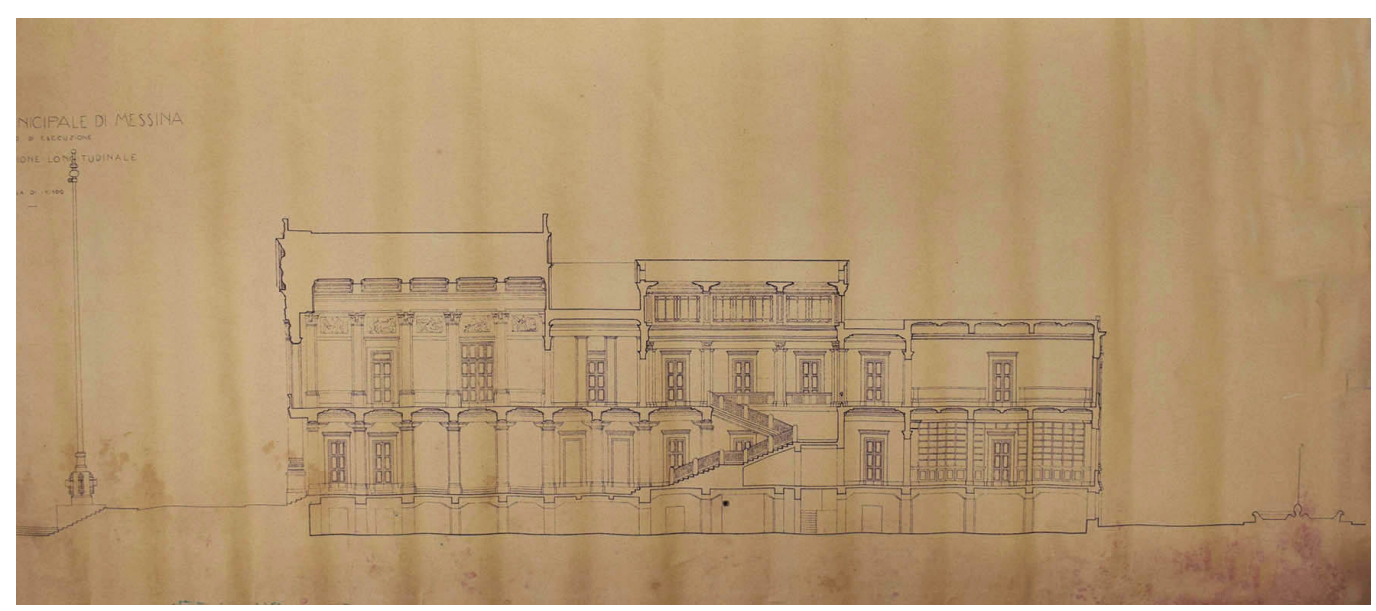


Fig. 7. Adolfo Romano, preparatory sketch fo the decoration of the party hall of the Municipality of Messina (private collection)

Fig. 8. Giuseppe Samonà, drawing for the Concorso della Nuova Cortina del Porto a Messina

head of block n. II, 1930 (IUAV Projects Archive).

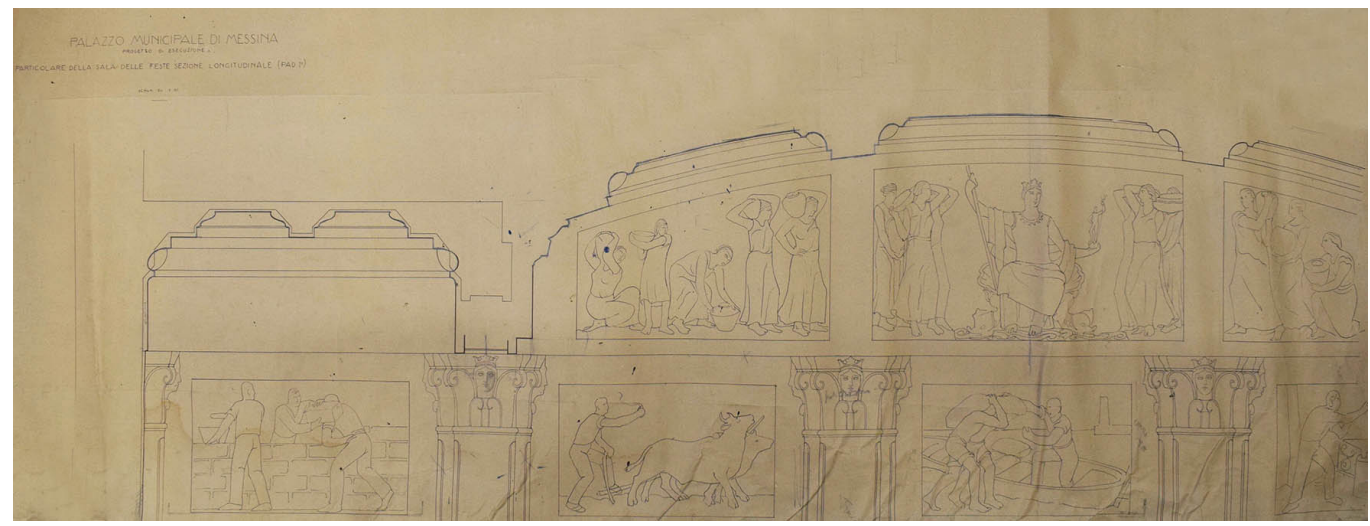

to the graphic expression of the past and that supporting the new figurative instances: this it can be exemplified through the tools and methods used such as charcoal, traditionally more suited to the enhancement of decorative apparatuses also emphasized by the use of shadows while the perspectives with the point of view placed at the bottom, to enhance the monumentality of the building, are the result of the adherence by professionals to new conditioned figurative trends deployed by the fascist regime (fig. 8).

Starting from 1930 the disciplines of representation in Messina find an adequate location within the Istituto di Disegno which, from 1935 and up to 1979 carries on its activities under the direction of Francesco Basile, passionate expert of history of architecture and author of numerous publications on teaching methods of drawing. Giuseppe Arena was trained at his school, among others, with his studies and surveys on the 'small towns' and, in particular, on the Calabrian Norman churches (fig. 9), Fabio Basile, Giovanni Favaloro, Pasquale La Spina and Mario Manganaro. Spending only a few lines in this context seems truly reductive on the activity of the latter: his works are certainly the testimony of an untiring drawing activity that has reconciled over the years the interests for the geometric aspects of representation with the observation and graphic restitution of reality through a substantial production of surveys "a vista" : although this activity is hardly practiced in current times, this typology of drawings remains of fundamental importance as Manganaro himself tells us since "base essenziale per la realizzazione dell'eidotipo di base, per le successive prese metriche e serve in generale per appropriarsi di quelle proprietà primarie e immediate dello spazio architettonico dei centri storici" [Manganaro 2000, p. 62] (fig. 10).

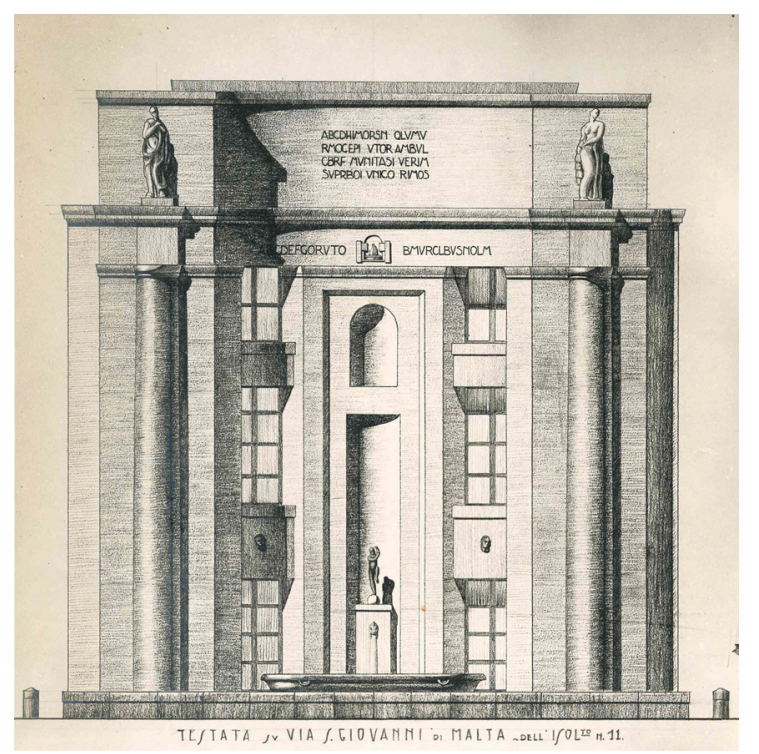


Fig. 9. Giuseppe Arena, survey Cathedral of Tro-

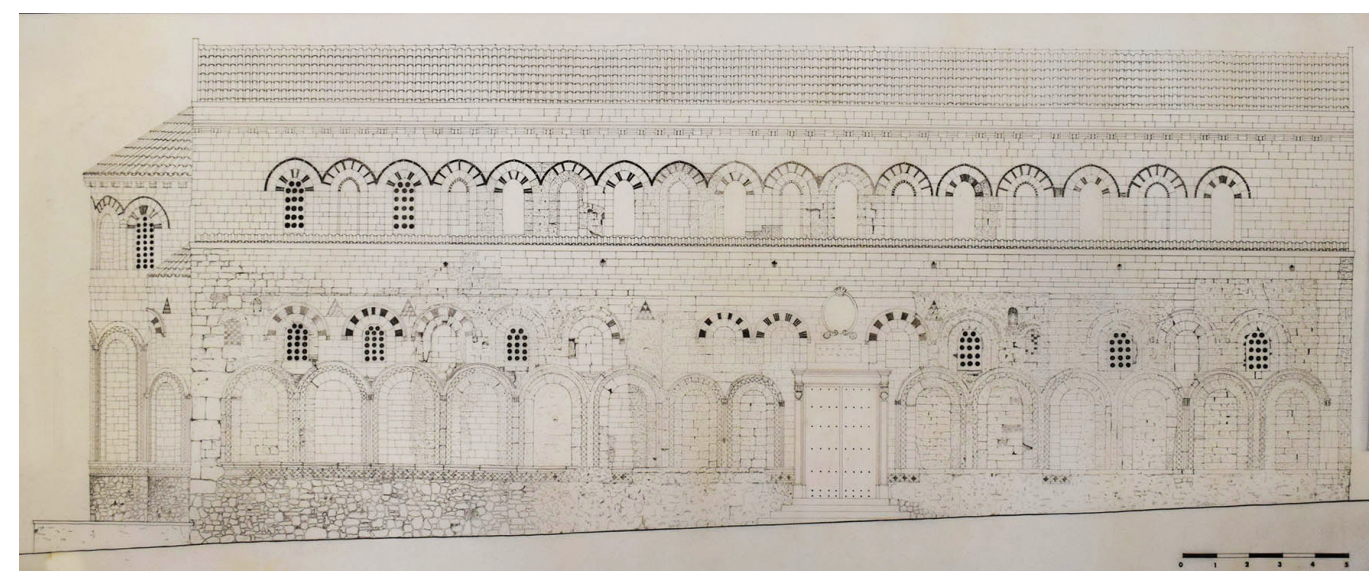

Fig. 10. Mario Manganaro, Piazza Armerina view

from the Cappuccini hill, 1997 (private collection)

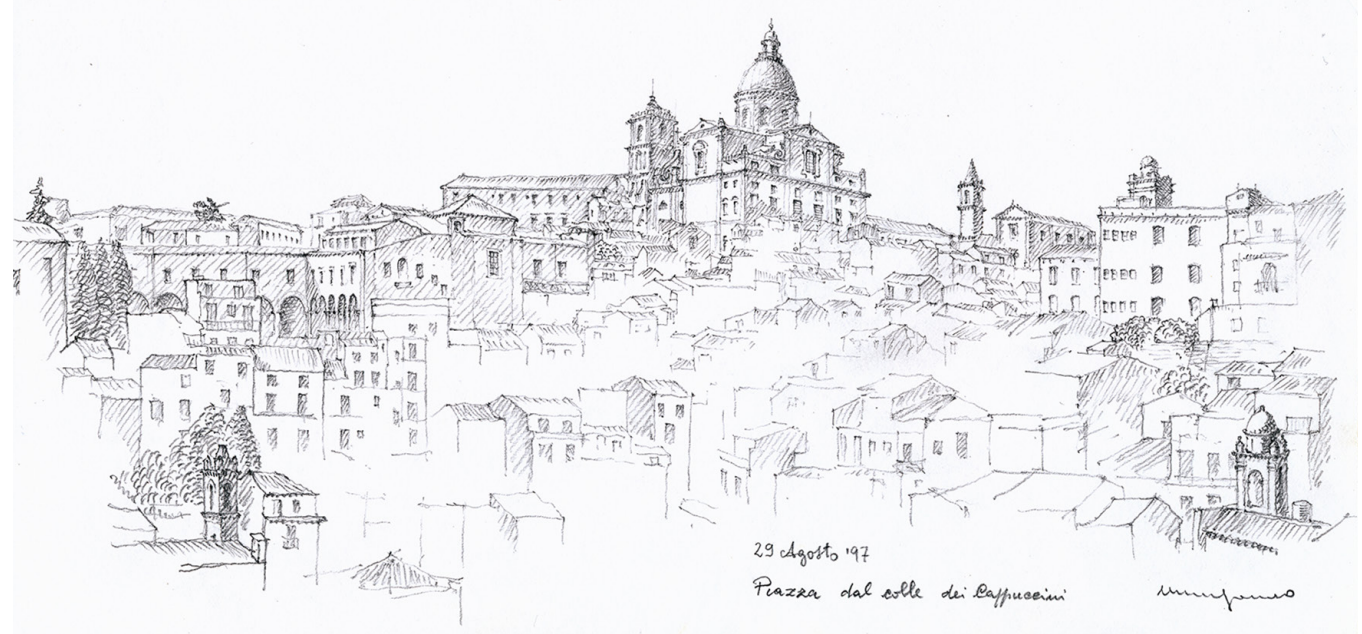


Fig. I I. Michela De Domenico, Gru watercolor and ink, 2013

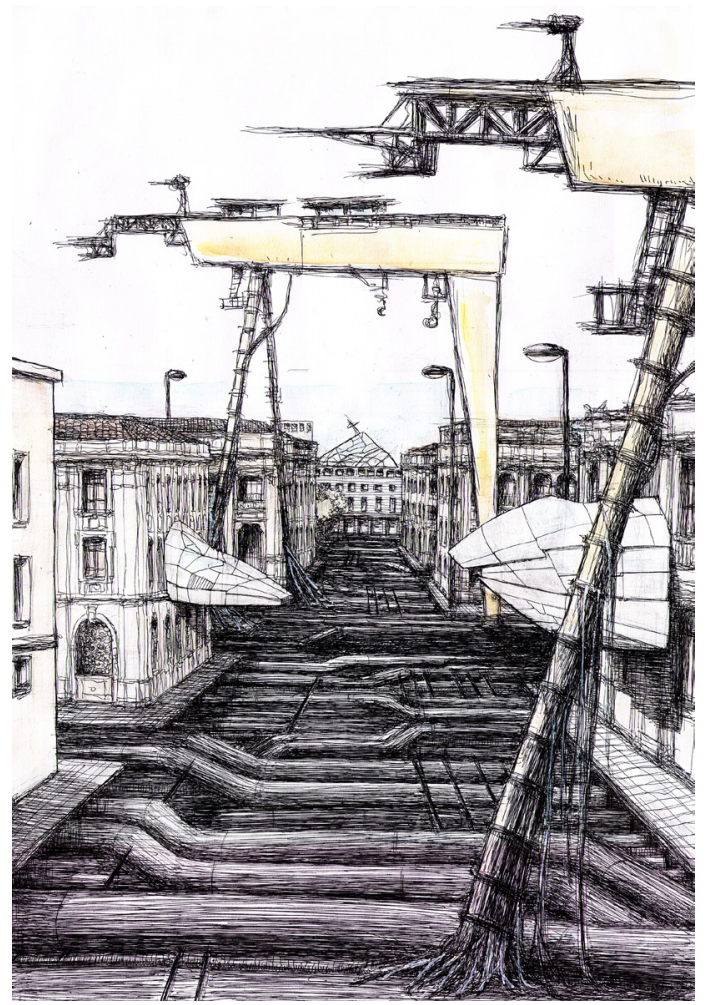

Starting from 1990, the activity of Istituto di Disegno will be followed up into the Department of Representation and Design within the Faculty of Engineering directed by Fabio Basile. This concise report on the exhibition concludes with a brief cross-section on the activities of those who in different capacities (teachers, doctoral students, students) in recent times have carried out critical analysis within the Department of Engineering concerning the themes of the design drawing and the transformation of the city. These are the elements that distinguish the innovative proposals by Michela De Domenico and Fabrizio Ciappina, both characterized by a visionary approach: for the first, the architectural design is investigated through the expressive peculiarities of the comic (fig. II), the second, in the proposed example, using a traditional tool such as chalk, deals with the theme of the reconstruction of a sudden "absence" in an attempt to compensate for an unexpected urban void (fig. I2) [2].

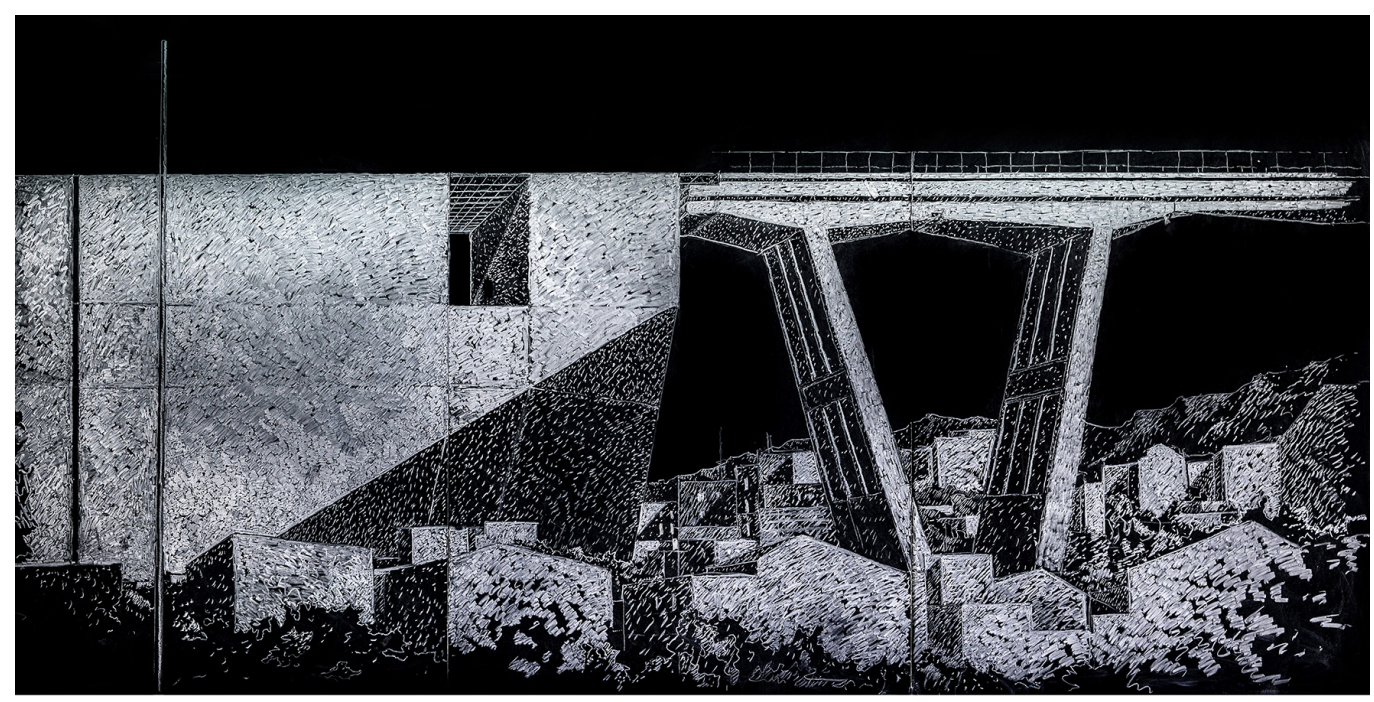

Fig. 12. Fabrizio Ciappina, Riparare l'Umano, nuov attraversamenti per Genova, ex Chemistry Classroom blackboard, University of Messina, chalk on 2018, white $\times 300 \mathrm{~cm}$. 


\section{Notes}

[I] Starting in 1929, the preparatory two-year period of Engineering within the Institute of Design of the Faculty of Sciences was active.

[2] The drawing on the cover is by Angelo Tinnirello (former student engineer). View of Messina from Forte San Salvatore, 2018 , made in pencil on cardboard.

\section{References}

Altadonna Alessio (2017). II rilievo come conoscenza complessa e integrata: il caso di studio della fontana di Orione in Messina. In Kiene Michael, D’Angelo Michela, Lo Curzio Massimo (a cura di). 1823 Hittorff a Messina. La scoperta di una città nuova. Messina: EDAS, pp. |83-|9|.

Di Giacomo Caterina ( 1998). II disegno a Messina fra i due secoli: retaggi accademici ed impulsi innovativi. In Barbera Gioacchino (a cura di). Gli Anni dimenticati. Pittori a Messina tra otto e novecento. Messina: Sicania, pp. I03-I I I.

Manganaro Mario (2000). Apparizioni di città. [Sceneggiatura]. In Aricò Nicola (a cura di). DRP Rassegna di Studi e Ricerche, 3 , pp. $45-72$.

Manganaro Mario (20 I7). Rilievo della fontana di Orione. Rapporto preliminare. In Kiene Michael, D'Angelo Michela, Lo Curzio Massimo (a cura di). 1823 Hittorff a Messina. La scoperta di una città nuova. Messina: EDAS, pp. I65-I81.

Rossi Michela (2012). La forma e la norma: il linguaggio dei segni. In Rossi Michela (a cura di). II disegno come ricerca. Strumenti grafici e modelli rappresentativi per il progetto. Santarcangelo di Romagna: Maggioli Editori, pp. 17-26.

Vernizzi Chiara (2005). Codici del disegno di progetto. Considerazioni sull'innovazione dei modi di rappresentazione determinata dalle mutate necessità operative. In Mochi Giovanni (a cura di). Teoria e pratica del costruire: saperi, strumenti, modelli. Esperienze didattiche e di ricerca a confronto. Atti del Seminario Internazionale. Ravenna, 27-29 ottobre 2005, vol. I, pp. 37I-380. Ravenna: Edizioni Moderna.

\section{Author}

Adriana Arena, Università di Messina, adarena@unime.it

To cite this chapter. Arena Adriana (2020). II percorso del Disegno a Messina: dal Collegio di Belle Arti al Dipartimento di Ingegneria. Resoconto di una mostra/The path of Drawing in Messina: from the College of Fine Arts to the Engineering Department. Report of an exhibition. In Arena A., Arena M., Brandolino R.G., Colistra D., Ginex G., Mediati D., Nucifora S., Raffa P. (a cura di). Connettere. Un disegno per annodare e tessere. Atti del $42^{\circ}$ Convegno Internazionale dei Docenti delle Discipline della Rappresentazione/Connecting. Drawing for weaving relationships. Proceedings of the 42th International Conference of Representation Disciplines Teachers. Milano: FrancoAngeli, pp. I 578- 1597. 